\title{
Humanitarian Intervention and the Jus Cogens Argument: A Critical Observation
}

\author{
Fajri Matahati Muhammadin* \\ DOI: https://doi.org/10.22304/pjih.v5n1.a4
}

Submitted: November 3, 2017 | Accepted: April 25, 2018

\begin{abstract}
The legality of humanitarian intervention has been debated for a long time, both on the level of scholarly works and inter-state politics. Most of the debates surround the sources of international law (international conventions, customary international law, etc.) or functions of the UN or the politics or a combination thereof. However, another level of debate is not usually observed much: the Jus cogens debate. Being a non-derogable norm under international law, the prohibition against the use of force is a classic example of a Jus cogens norm, and humanitarian intervention is argued to breach it. This paper observed and explored the concept of Jus cogens, how is it constructed, and found that humanitarian intervention is not a breach of Jus cogens.
\end{abstract}

Keywords: humanitarian intervention, Jus cogens, use of force.

\section{Intervensi Humaniter dan Argumen Jus cogens: Sebuah Observasi Kritis}

\begin{abstract}
Abstrak
Legalitas dari intervensi kemanusiaan telah diperdebatkan sejak lama, baik melalui karya ilmiah para ahli maupun dalam politik praktis antar negara. Mayoritas perdebatan berpusat pada sumber-sumber hukum internasional (konvensi internasional, hukum kebiasaan internasional, dan lain-lain), atau fungsi PBB atau perpolitikan atau perpaduan keduanya. Namun, ada satu level perdebatan yang kurang diamati: perdebatan Jus cogens. Sebagai norma yang tidak dapat dikurangi menurut hukum internasional, larangan penggunaan kekerasan bersenjata merupakan contoh klasiknorma Jus cogens, dan intervensi kemanusiaan diklaim telah menentangnya. Paper ini mencermati dan mengeksplorasi konsep Jus cogens, bagaimana terbentuknya, dan menemukan bahwa intervensi kemanusiaan bukanlah pelanggaran Jus cogens.
\end{abstract}

Kata kunci: intervensi kemanusiaan, Jus cogens, penggunaan kekuatan bersenjata.

\section{A. Introduction}

Humanitarian intervention debates have been among the major debates in international law and politics. The United Nations Security Council (UNSC) has agreed to enable the use of hostile force under authority of Chapter VII of the Charter of the United Nations (UN Charter), ${ }^{1}$ but the resort to such act by individual state(s) remain controversial, and the norms surrounding it evolves but has yet to be clear.

PADJADJARAN Journal of Law Volume 5 Number 1 Year 2018 [ISSN 2460-1543] [e-ISSN 2442-9325]

\footnotetext{
Lecturer at the Department of International Law, Faculty of Law, Universitas Gadjah Mada, fajrimuhammadin@ ugm.ac.id, S.H. (Universitas Gadjah Mada), LL.M. (University of Edinburgh), Ph.D Cand. (International Islamic University of Malaysia).

1 See Article 2(7), 42, and 43 of the Charter of the United Nations, 26 June 1945 (UN Charter).
} 
There are many cases where the use of force has been resorted to with humanitarian purposes, including: the Vietnam invasion to Cambodia (1978), ${ }^{2}$ and NATO intervention to the civil war in Yugoslavia. ${ }^{3}$ The reliance towards the doctrine of humanitarian intervention has been elusive, and states who conduct the doctrine tend to be somewhat 'cheeky' in justifying their grounds, such as how the coalition of UK, USA, and France, in intervening against Iraq's repression towards the Kurds and Shiites, claimed that they were merely applying an 'implicit authorization' of an UNSC Resolution. ${ }^{4}$ The debates usually tend to go around the interpretation towards relevant international treaties or instruments on rules related to the use of force, for instance the UN Charter Article 2(4) and Chapter VII, Rome Statute of the International Criminal Court 1998 (Rome Statute) and the UN General Assembly Resolutions concerning the Acts/Crimes of Aggression.

However, instead of many arguments surrounding humanitarian intervention, this paper will focus on the argument from the Jus cogens perspective. Some argue that if the situation within a state has indeed escalated to a humanitarian crisis so much that it involves gross breaches of human rights principles which have been recognized as Jus cogens, intervention must be done. ${ }^{5}$ However, there is a prohibition against the use of force (hereinafter, The Prohibition) rising to the level of Jus cogens. Therefore, others may argue that if the use of force is a breach of Jus cogens, while humanitarian intervention uses force, would it not follow that humanitarian intervention is a breach of Jus cogens? ${ }^{6}$

As the previous paragraph suggests, this paper will draw a fine line between intervention to civil wars for political gain (as USA did in Nicaragua) and those done for humanitarian purposes (as NATO did in Yugoslavia), and focus on the latter. For convenience, the term that will be used would be 'humanitarian intervention'. This paper will argue that the confusion in the Jus cogens argument should not persist, and that a new view should be adopted that humanitarian intervention is not a breach of Jus cogens.

\section{B. Jus cogens and Erga omnes \\ 1. Jus cogens}

Jus cogens, a latin phrase literally meaning 'the compelling law', is a norm that is "...the highest hierarchical position among all other norms and principles.... deemed to be 'peremptory' and non-derogable". 'Shall any law come in conflict to the Jus cogens, the principle of lex superiori derogat legi inferiori, ${ }^{8}$ applies and such laws

Christine Gray, International Law and the Use of Force, $3^{\text {rd }}$ edition, New York: Oxford University Press, 2008, p. 33.

Ibid., p. 39.

Ibid., p. 36.

Ibid., p. 48.

Ibid., p. 48.

M. Cherif Bassiouni, "International Crimes: Jus cogens and Obligatio Erga omnes," in Law \& Contemporary Problems, Vol. 59, Issue 4, 1996, p. 67.

8 Sudikno Mertokusumo, Mengenal Hukum: Suatu Pengantar, Yogyakarta: Liberty Press, 2006, p. 74. 
are nulled, including treaties. ${ }^{9}$ There are no clear criteria to determine a Jus cogens norm. ${ }^{10}$ The Vienna Convention on The Law of Treaties 1969 (VCLT) came up with article 53 which mentions only the effect "...recognized by the community of States as a whole as norms from which no derogations are permitted and may be replaced only by norms having the same character."

Positivists would mention certain structural norms as Jus cogens, such as pacta sunt servanda. ${ }^{11}$ This view is flawed since treaties can be annulled when conflicted with Jus cogens. The school of natural law, where the idea of Jus cogens came, ${ }^{11}$ may be more appealing. Natural law sees law as a standard of human conduct, ${ }^{12}$ and should be based on values such as morality and humanity..$^{13}$ To this, Bassiouni suggests that there are two alternatives doctrinal bases to determine Jus cogens, namely: ${ }^{14}$

1. the basis that shocks the conscience of humanity, and/or

2. the basis that threatens international peace and security.

The first element which shows links to principles of humanity is strongly moral related. The laws regulating conduct of war (international humanitarian law or IHL) certainly started from morality and humanity, ${ }^{15}$ which has then been recognized as among the Jus cogens in the advisory opinion issued by International Court of Justice on the legality of the threat or use of nuclear weapons in 1996 (Legality of Nuclear Advisory Opinion). ${ }^{16}$

In other laws that are recognized as Jus cogens, links to natural law are apparent as well. The most obvious example would be human rights. The entire preamble of the Universal Declaration of Human Rights (UDHR) talks about human dignity and rights and the importance of the international world to defend it. Then, a large number of legally binding conventions which are generally ratified by a very large numbers of states, which include but not limited to the International Covenant on Civil and Political Rights of 1966, the International Covenant on Economic, Social, and Cultural Rights, the Convention on the Elimination of All Forms of Discrimination Against Women of 1979, the Convention on the Rights of the Child of 1989, and many others refer the UDHR in their preamble.

\footnotetext{
See Article 53 of the Vienna Convention on the Law of Treaties Between States 1969 (VCLT).

10 Stefan Kadelbach, "Jus cogens, Obligations Erga omnes, and Other Rules - The Identification of Fundamental Norms," in Christian Tomuschat and Jean-Marc Thouvenin (eds.), The Fundamental Rules of the International Legal Order: Jus cogens and Erga Omnes, Leiden-Boston: Martinus Nijhoff Publishers, 2006, pp. 28-29.

11 Władysław Czapliński, "Jus cogens and the Law of Treaties", in Christian Tomuschat and Jean-Marc Thouvenin (eds.), Op.cit., p. 83.

12 Mark C. Murphy, "Natural Law Theory", in M.P. Golding and W.A. Edmundson (eds.), The Blackwell Guide to the Philosophy of Law and Legal Theory, Oxford: Blackwell Publishing, 2005, p. 16.

13 Abdul Ghoful Anshori, Filsafat Hukum: Sejarah, Aliran, dan Perkembangannya, Yogyakarta: Gadjah Mada Press, 2006, pp. 87-88.

14 M. Cherif Bassiouni, Op.cit., p. 69.

15 Eva Wortel, "Humanitarians and their moral stance in war: the underlying values", in International Review of the Red Cross, Vol. 91, Issue 876, 2009, p. 781.

16 International Court of Justice, Legality of the Threat or Use of Nuclear Weapons, Advisory Opinion, I.C.J. Reports, 1996 (Legality of Nuclear Advisory Opinion), p. 226, para. 80.
} 
However, a very essential part would be the universal recognition of states, as mentioned in Article 53 of the VCLT. Bassiouni mentions in his article that, among the legalistic criteria to determine Jus cogens crimes, there has to be recognition of such crimes to be customary international law $(\mathrm{CIL})^{17}$ for instance, the Pinochet Case. ${ }^{18}$ Recognition is important as it is an element of CIL. ${ }^{19}$ This is perhaps why some scholars suggest that Jus cogens is just the same as $\mathrm{CIL} .{ }^{20}$ This view is incorrect because there has to be a 'non-derogable' nature unique to Jus cogens (the normal non-Jus cogens CIL can be derogated by treaties ${ }^{21}$ ), where the recognition of such is another legalistic criterion in Jus cogens determination. ${ }^{22}$

\section{Obligatio Erga omnes}

Obligatio erga omnes means 'obligatory to all'. This is a mere consequence of Jus cogens: if a law is a 'compelling law' (Jus cogens) then it is 'obligatory to all' (obligatio erga omnes), meaning that a Jus cogens is a requirement for obligatio erga omnes, but obligatio erga omnes is not a requirement for Jus cogens. ${ }^{23}$

Kadelbach notes that obligatio erga omnes is a concept of state responsibility compared to Jus cogens as a substantive law. ${ }^{24}$ This makes sense, as the Jus cogens is the norms to adhere to, while obligatio erga omnes is the responsibility to carry them out. They can be mixed up to each other, most likely because they both eventually are justified by the same underlying norms, ${ }^{25} \mathrm{e} . \mathrm{g}$. if the laws of war has attained the status of Jus cogens, then it is obligatio erga omnes to abide by the laws of war (both are elements of law anyways). ${ }^{26}$

However, they are both manifested in different sets and natures of rules. An example to that would be the laws of war: Grave Breaches of the Geneva Conventions 1949 (Grave Breaches of the GC) ${ }^{27}$ are the breach of Jus cogens norms, while the obligations to respect the convention in all circumstances ${ }^{28}$ and to provide penal sanctions ${ }^{29}$ are the obligatio erga omnes.

17 M. Cherif Bassiouni, Op.cit., p. 68.

18 House of Lords, R. v Bow Street Stipendiary Magistrate Ex. P. Pinocet Ugarte, No. 3, 1 A.C, 2000, p. 147.

19 Malcolm N. Shaw, International Law, $6^{\text {th }}$ edition, New York: Cambridge University Press, pp. 72-93; see also: International Court of Justice, Military and Paramilitary Activities in and against Nicaragua (Nicaragua v. United States of America), Judgement, I.C.J. Reports, 1986 (Nicaragua case), p. 14, para. 188.

Ibid.

Ibid., pp. 72-73.

Stefan Kadelbach, Op.cit., p. 26.

Stefan Kadelbach, Op.cit., p. 27.

See definition of 'law' in Bryan A. Garner (ed.), Blacks Law Dictionary, $9^{\text {th }}$ edition, Minnesota: Thomson West, 2009, p. 962. and 'international law' in Malcolm N. Shaw, Op.cit., p. 1.

27 Article 50, 51, 130, and 147 of the First Geneva Convention for the Amelioration of the Condition of the Wounded in Armies in the Field 1949 (GC I), Second Geneva Convention for the Amelioration of the Condition of the Wounded, Sick, and Shipwrecked Members of Armed Forces as Sea 1949 (GC II), Third Geneva Convention relative to the Treatment of Prisoners of War 1949 (GC III), and Fourth Geneva Convention relative to the Protection of Civilians in Time of War 1949 (GC IV) respectively.

28 Common Article 1 to the Geneva Conventions.

29 Article 49, 50, 129, and 146 of the GC I, GC II, GC III, and GC IV respectively. 


\section{The Prohibition}

\section{The Prohibition as a Jus cogens Norm}

The use of force can be very catastrophic. It had caused wide world wars that reformed the world's human rights and humanitarian law system. ${ }^{30}$ Such horrors brought the UN that we have today, with the obligation to refrain from the use of force set in Article 2(4) of the UN Charter (The Prohibition). It does not have to take a world war to feel strongly against any use of force, such as two states involved in international armed conflicts (e.g. the USA invasion to Iraq in 2003), ${ }^{31}$ internal armed conflicts (e.g. the government against rebel war in Syria), ${ }^{32}$ or even internal disturbances between two non-state groups (e.g. the fighting between the Dayak and Madura tribes in Central Borneo, Indonesia) ${ }^{33}$ can rise to such an extreme level.

Certainly, there is no doubt that The Prohibition is a rule recognized universally by states. It is a rule of $\mathrm{ClL}^{34}$ and enshrined in the UN Charter (currently 193 states). ${ }^{35}$ This reflects one of the characteristics of Jus cogens in Article 53 of the VCLT that is "...accepted and recognized by the international community of States...".

The status of The Prohibition of the use of force as Jus cogens is very popular. In drafting the VCLT, the International Law Commission (ILC) noted The Prohibition as a Jus cogens examples. ${ }^{36}$ The ICJ in the Nicaragua case might have said the same. ${ }^{37}$ Numerous writers also hold that aggression which is the most dangerous form of the illegal use of force ${ }^{38}$ as breach of Jus cogens. ${ }^{39}$ Even by writers who seem to are critical towards the idea of Jus cogens in general, such as Ulf Linderfalk, ${ }^{40}$ The Prohibition is named as the 'least controversial example of all'. ${ }^{41}$

\footnotetext{
Stefan Kadelbach, Op.cit., pp. 782-784.

31 Huffington Post, "Iraq Death Toll Reaches 500,000 Since Start Of U.S.-Led Invasion, New Study Says", https:// www.huffingtonpost.com/2013/10/15/iraq-death-toll n 4102855.html, accessed on October 2017.

32 CNN, "Syrian Civil War Fast Facts", https://edition.cnn.com/2013/08/27/world/meast/syria-civil-war-fast-facts/ index.html, accessed on October 2017.

33 Human Rights Watch, "Indonesia: The Violence in Central Kalimantan (Borneo)", http://www.hrw.org/legacy/ backgrounder/asia/borneo0228.htm, accessed on October 2017.

34 James A. Green, "Questioning the Peremptory Status of the Prohibition of the Use of Force", Michigan Journal of International Law, Vol. 32, 2011, p. 222.

35 United Nations Treaty Collection, "Charter of the United Nations and Statute of the International Court of Justice", http://treaties.un.org/Pages/ViewDetails.aspx?src=TREATY\&mtdsg_no=l-1\&chapter=1\&lang=en, accessed on October 2017.

36 Reports of the International Law Commission to the General Assembly, U.N. Doc. A/6309/Rev.1, 1966, in Year Book of the International Law Commission Vol. II, U.N. Doc. A/CN.4/SER.A/1966/Add.1, p. 247 (Commentary to Article 50).

37 Nicaragua case, para. 190.

38 See the Annex of the United Nations General Assembly Resolution No. 3314 (UNGA Resolution A/RES/3314), para. 5 of the Preambulatory Clauses.

39 Malcolm N. Shaw, Op.cit., p. 126; M. Cherif Bassiouni, Op.cit., p. 68.

40 See his works generally: Ulf Linderfalk, "Normative Conflict and the Fuzziness of the International lus Cogens Regime," Zeitschrift Für Ausländisches Öffentliches Recht Und Völkerrecht, Vol. 69, 2009, pp. 961-77; Ulf Linderfalk, "The Effect of Jus cogens Norms: Whoever Opened Pandora's Box, Did You Ever Think About the Consequences?," European Journal of International Law, Vol. 18, Issue 5, 2007, pp. 853-71.

${ }^{41}$ Ulf Linderfalk, "The Effect of Jus cogens Norms: Whoever Opened Pandora's Box, Did You Ever Think About the Consequences?", Ibid., p. 859.
} 
In the UN, The Prohibition has a special place. It is enshrined clearly in Article 2(4) of the UN Charter, the principle of sovereign equality is the basis of UN operations (Article 2(1) of the UN Charter). However, in serious breach of peace or aggression, the UNSC, may under Chapter VII override sovereignty (Article 2(7) of the UN Charter) and, choose from an array of less-hostile to hostile means to neutralize such threats to peace (Chapter VII, and Articles 42-43 of the UN Charter). This is how much the use of force is negatively seen. On all these terms, it may seem very conceivable that The Prohibition is definitely among the Jus cogens.

\section{The Prohibition: Jus cogens?}

Despite overwhelming support for The Prohibition as Jus cogens, such proposition turns out not to be without problems. If the matter is critically analyzed, on might reach some different conclusions. The result of this critical analysis will be a crucial element in resolving the Jus cogens problem in favor or against humanitarian intervention.

\section{a. Leeway Implied in Article 2(4) of the UN Charter}

To analyze this, one may start with the most obvious source of doubt. In fact, Article 2(4) of the UN Charter, which has been the champion of evidence of the Jus cogens status of The Prohibition, ${ }^{42}$ never says that the use of force is altogether prohibited. The exact wording of that article goes as follows: "All Members shall refrain in their international relations from the threat or use of force against the territorial integrity or political independence of any state, or in any other manner inconsistent with the Purposes of the United Nations". ${ }^{43}$

The wordings may imply that there may be instances of uses of force that are 'not in a manner inconsistent with the purposes of the United Nations' which means, consequently, requires no refraining. There is no question on the authority of the UNSC to resort to force under Chapter VII, specifically in Article $43,{ }^{44}$ but it may be important to note that no provisions refer to this in Article 1 of the UN Charter (which is the 'Purposes' of the UN).

Furthermore, one of the arguments put by James Green, who is skeptical on the Jus cogens status of The Prohibition, may have some truth in it. He highlights the relation between the prohibition against 'the use of force' and 'the threat of force'. ${ }^{45}$ The way the ICJ constructed the general 'principle of non-use of force' (the word that the ICJ puts it) in the Nicaragua Case, was to see that the 'threat of force' is equally prohibited as the 'use of force'. ${ }^{46}$ Similar tone is also mentioned in the Legality of Nuclear Advisory Opinion. ${ }^{47}$ The simple logical conclusion to that is 'a

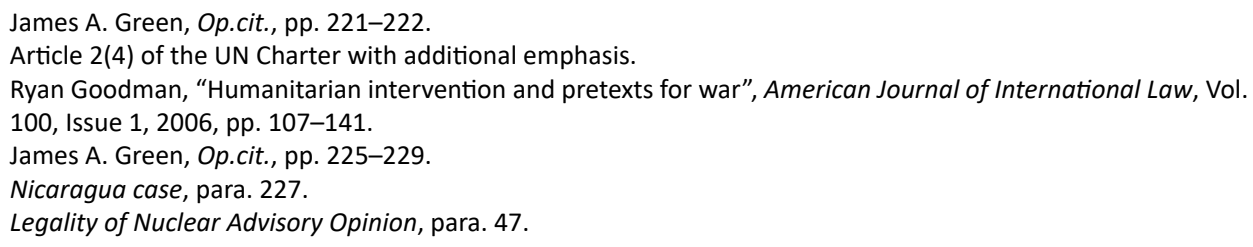


threat of force' is substantively of the same status as 'a use of force', suggesting that the threat of force is also a Jus cogens norm.

Having that said, the construction of The Prohibition becomes rather uncertain. In the previously mentioned Legality of Nuclear Advisory Opinion, the exact same reference notes how the magnitude of the threat of force is highly dependent on the use of force. This is a clear implicit message that the threat of force in itself is not the real problem. Not to mention, writers have noted that states have seen that the real big issue here is actually the use, not the threat of force. ${ }^{48}$ The implication to this is clear: the threat of force simply cannot be a Jus cogens. But if the ICJ construction mentions both rules substantively the same, it is then either: the use of force is also not a Jus cogens like threat of force, or the threat of force is also a Jus cogens like use of force. Both scenarios do not seem to make much sense.

\section{b. Problems on Recognition as Jus cogens.}

The wordings of Article 53 of the VCLT require such norm to be recognized as: a) a general customary law, and b) a Jus cogens. ${ }^{49}$ James Green has observed that, while The Prohibition has been generally accepted as a rule of $\mathrm{CIL}$, it has really lack evidence of recognition as Jus cogens. Green's first observation was on the recognition by the ICJ through the Nicaragua case and the ILC. There, he noted that the claims of the Jus cogens status of The Prohibition by these two authorities do not cite any evidence of state recognition. ${ }^{50}$

Green's second observation was to actually seek and examine the evidences himself. In the debates during the Conference on the VCLT regarding what later became Article 53 (by 32 states), only fourteen states mentioned that The Prohibition is indeed (or might be) a Jus cogens norm, as compared to the total 103 states involved in the Conference on the VCLT. ${ }^{51}$ Further, he examined numerous international forums which discussed the Jus cogens status of The Prohibition (numerous UN level conferences, including: General Assembly and UNSC sessions). ${ }^{52}$ In these observations, while there was no denial that the use of force is indeed prohibited as a rule of $\mathrm{CIL}$, quite a substantial amount of states have indeed disagreed to the Jus cogens status of it.

However, what lack in this argument is the lack of clarity in the nature of these non-recognitions. Do these states who disagreed with the Jus cogens status of The Prohibition think of every forms of use of force to fall under the category? If that is so, then we can see that such lack of recognition does not dismiss The Prohibition as Jus cogens entirely. This will be explained in the next points.

\footnotetext{
48 James A. Green, Loc.cit.

49 See also: James A. Green, Op.cit., pp. 243-244; Ulf Linderfalk, "The Effect of Jus cogens Norms: Whoever Opened Pandora's Box, Did You Ever Think About the Consequences?", Op.cit., p. 861.

James A. Green, Loc.cit.

Ibid., pp. 245-246.

Ibid., pp. 246-252.
} 


\section{Certain Exceptions to the Norm}

The most important element of Jus cogens is its non-derogable nature. ${ }^{53}$ The facts show that the prohibition to the use of force may be derogable. The principle of self-defense is a major example. Article 51 of the UN Charter explicitly allows the use of force when an existing armed conflict has occurred against the state. If The Prohibition is indeed a Jus cogens norm, then Article 51 would have been nulled, as what Article 53 of the VCLT provides. As James Green observes, Article 5 of the North Atlantic Treaty 1949 would also be nulled as it provides the obligation of the North Atlantic Treaty Organization (NATO) members to, when one is under attack, also jump in..$^{54}$

A Jus cogens, though, can be derogated by another Jus cogens. If self-defense is itself a Jus cogens norm, Green's previous argument would fall. However, while self-defense is $\mathrm{CIL}^{55}$ there is no evidence to indicate the Jus cogens status of selfdefense. ${ }^{56}$ Ulf Linderfalk made interesting additional points on this, stating that selfdefense cannot be a Jus cogens on two grounds.

The first ground is that there are two general kinds of self-defenses recognized in CIL: the classic type of self-defense in Article 51 of the UN Charter, and anticipatory self-defense. However, Article 51 only allows self-defense when a state is being attacked by another state, meaning that anticipatory self-defense would be outlawed. If the rights to self-defense is a Jus cogens, and anticipatory self-defense is part of it, then Article 51 is a breach of Jus cogens and is therefore nulled..$^{57}$

This first ground does not seem to make good sense, though. If Linderfalk's argument was true, and Article 51 was nulled, the rule that will then take place would be the rights to self-defense in CIL, which includes both the classic selfdefense as well as the anticipatory self-defense. Hence, the provisions in Article 51 were restored back again and the new development nicely comes in as well.

Linderfalk's second ground is more important. He mentions the fact that the customary law of self-defense has evolved, and the Jus cogens status may not evolve along with it. He cited an example of how the classic law of self-defense only recognizes an attack from state actors, while the tragedy of the $9 / 11$ terrorist attack and what came next (the 'war on terror' against the Al-Qaeda) seems to start a recognition of self-defense towards non-state actors as well. ${ }^{58}$

As previously mentioned, a Jus cogens norm would require recognition as: a) a general customary law, and b) a Jus cogens. Linderfalk seems rather skeptical on whether a new customary law has indeed evolved in such short period of time. ${ }^{59}$ But

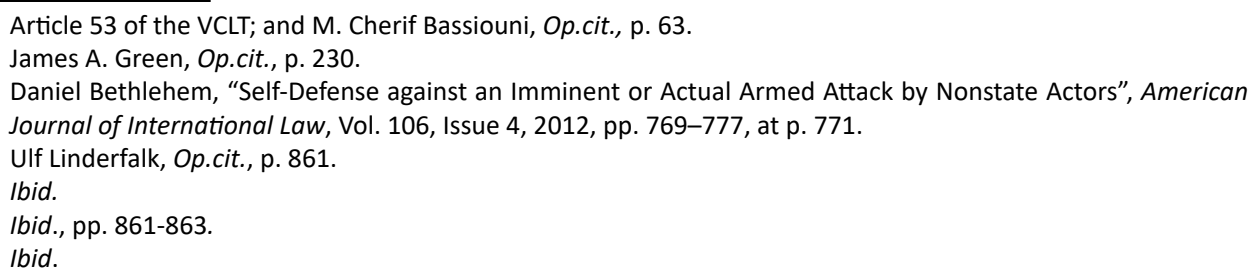


even if there is indeed a new customary law evolving to allow self-defense against non-state actors, and if it is assumed that the inherent rights to self-defense is also a Jus cogens norm, then all we have to justify the invasion to Afghanistan is the new CIL.

However, we do not have the recognition as Jus cogens for this new type of self-defense yet. Therefore, under assumption of the Jus cogens status of the classic self-defense, self-defense against non-state actors would become a breach of the Jus cogens norm of The Prohibition. One could not have justified that act positively; neither can anything be used to preclude wrongfulness because none of the preclusion to wrongfulness may be invoked in breach of the Jus cogens. ${ }^{60}$

From this, we could see that if self-defense can derogate The Prohibition, while the former is not a Jus cogens, the latter is not a Jus cogens norm either.

\section{Dealing with Exceptions: Not Jus cogens or Specific Jus cogens?}

As mentioned earlier, the rights to self-defense can be an exception towards The Prohibition. However, there are at least two different ways to see this.

The first way to see this, according to what James Green seems to vehemently propose, is that The Prohibition may not be a Jus cogens norm after all. This may have its own persuasion, but there is another perspective to see it. The second way to see it is that it is only the use of force that is not used in context of self-defense that is recognized as a Jus cogens norm. In other words, the Jus cogens norm is the prohibition of offensive use of force.

Most (if not all) references towards The Prohibition in Jus cogens context have been in response to offensive uses of force. An example to this is the Nicaragua case (the USA attacks were declared as use of force, and their claim of collective self-defense was rejected). ${ }^{61}$ What is acknowledged as a Jus cogens crime is also aggression, which is an offensive use of force. There seems to be a universal recognition to this. The UNGA Resolution A/RES/3314, mentioning in the annex's preambulatory clause paragraph 5 that "...aggression is the most serious and dangerous form of the illegal use of force...," was adopted without vote and also endorsed by the Kampala Agreement, and also adopted without vote. ${ }^{62}$

A similar argument was posed in context of amnesty laws for Jus cogens crimes. The dilemma was that the Jus cogens status of crimes, according to writers and case laws, would be entitled to an erga omnes obligation to prosecute. ${ }^{63}$ However, in certain gravity of conflicts involving these Jus cogens crimes, amnesty laws may be

60 Article 26 of the Draft Articles on Responsibility of States for Internationally Wrongful Acts, with commentaries, 2001 (ILC Articles on State Responsibility).

Nicaragua case, Operative parts of Judgment, count 2 and 4.

Annex I of the Rome Conference Resolution No. RC/Res.6.

3 M. Cherif Bassiouni, Op.cit., p. 63; International Criminal Tribunal for the Former Yugoslavia (ICTY), Prosecutor vs Furundzija, Trials Chamber Judgment, IT-95-17/1-T, para. 155. (Furundzija case). 
needed to encourage peace processes and cease such hostilities. ${ }^{64}$ Would amnesty laws, in these cases, be a breach of Jus cogens?

Yasmin Naqvi correctly observed that, learning from the Furundzija case, only amnesty laws that is "...tantamount to authorizing, condoning or recognizing as lawful the situation created by the illegal act..." ${ }^{65}$ would be a breach of Jus cogens. In other words, some kinds of amnesty laws for Jus cogens crimes are a breach of Jus cogens, while others are not. This is a similar approach to The Prohibition and its exception in case of self-defense.

Green did not seem to be in favor of this approach. He says that 'cherry-picking' rules and norms, compiling them, are unclear and undesirable for a norm of Jus cogens. ${ }^{66}$ Further, he raised concerns of the lack of clarity in the concept of selfdefense (whether anticipatory self-defense is recognized or not etc.). ${ }^{67}$ The validity of this contention is questionable, as there is no rule of CIL that requires 'simplicity'. It is interesting how Green, while saying that there is lack of clarity, also manages to put the complicated-and-cherry-picked norms in one line anyways which somewhat solves the problem. ${ }^{68}$

Therefore, it can be concluded that not all uses of forces are evidently breaches of Jus cogens.

\section{Humanitarian Intervention \\ 1. Civil War, Jus cogens, and Obligatio Erga omnes}

Civil wars have always been catastrophic. The civil war in Darfur has resulted to an estimate of almost 300.000 deaths and 2.6 million displaced, ${ }^{69}$ while the Yugoslavia wars had an estimate of 140.000 deaths and four million displaced. ${ }^{70}$ The conflict in Syria, which is still on-going, as of now has an estimate of 400.000 deaths counting. ${ }^{71}$ Within those conflicts, there have been allegations of breaches of Jus cogens such as war crimes, crimes against humanity, and even genocide. ${ }^{72}$

64 For further analysis, see: Judge Mahomed's Dissenting Opinion in Constitutional Court of South Africa, Azanian Peoples Organization (AZAPO) and Others v President of the Republic of South Africa and Others, CCT17/96, ZACC 16, 1996 (AZAPO Case), paras. 17-22., Alex Borain, "Truth and Reconciliation in South Africa: The Third Way", in R.I. Rotberg and D. Thompson (eds.), Truth v. Justice: The Morality of Truth Commission, Princeton: Princeton University Press, 2000, p. 143; Michael .P. Scharf, "The Amnesty Exception to the Jurisdiction of the International Criminal Court", Cornell International Law Journal, Vol. 32, 1999, p. 507, at pp. 507-27.

65 Yasmin Naqvi, "Amnesty for war crimes: Defining the limits of international recognition", International Review of the Red Cross, Vol. 85, Issue 851, 2003, pp. 583-626, at pp. 613-4.

66 James A. Green, Op.cit., pp. 233-234.

67 Ibid., pp. 235-236.

68 Ibid., p. 234.

69 BBC News, "Darfur Death Toll Rises to Two-Year High in Sudan”, http://www.bbc.com/news/10259604, accessed on October 2017.

70 International Center for Transitional Justice, "Transitional Justice in the Former Yugoslavia", http://ictj.org/ sites/default/files/ICTJ-FormerYugoslavia-Justice-Facts-2009-English.pdf, accessed on October 2017.

1 CNN News, "Syrian Civil War Fast Facts", Op.cit.

72 Report of the International Commission of Inquiry on Darfur to the United Nations Secretary General, "About the ICTY", http://www.icty.org/en/about, accessed on October 2017, Telegraph News, "Everyone in Syria is bad now', says UN war crimes prosecutor as she quits post", https://www.telegraph.co.uk/news/2017/08/07/ everyone-syria-bad-now-says-un-war-crimes-prosecutor-quits-post/, accessed on October 2017. 
There is no question on whether or not those committed crimes have achieved the status of Jus cogens. Most (if not all) treaties related to those crimes are both recognized as part of CIL, and also having Jus cogens status as well. The Rome Statute, which encompasses all of those crimes, implies that in its preamble. ${ }^{73}$ All the GCs, the grave breaches of which are war crimes, ${ }^{74}$ mentions in their first article that the provisions of those conventions must be "...respected in all times...". All human rights treaties, mostly are close to universal ratification, cite the UDHR, which's preamble mentions that human rights are "...inalienable..." (although the idea that all human rights is Jus cogens may be a bit stepping too far). ${ }^{76}$

All of the aforementioned sources do not only affirm the Jus cogens status, but also provide obligatio erga omnes, as they all have provisions to oblige all states to do certain things, such as to prevent and punish perpetrators of war crimes. ${ }^{80}$ Most especially, the ILC has mentioned that it is an emerging duty to cooperate to bring an end to breaches of Jus cogens, through lawful means. ${ }^{77}$

It is an obligation under the UN Charter to always resort to peaceful means first. ${ }^{78}$ However, if that fails, hostile measures of many ranges can be adopted under Chapter VII of the UN Charter. On many occasions, it is indeed the UNSC that has acted harshly to intervene in cases of civil wars to put an end to them. An example to this would be the measures applied to Libya through UNSC Resolution S/RES/1973, which authorizes various hostile measures including air strikes and arming rebel groups. This intervention to Libya, despite a number opposition from countries (mostly either by allies of Libya in the African Union, or worried about the intervention forces attacking civilians), ${ }^{79}$ was also highly supported by a large number of states and was perfectly legal.

The NATO intervention to Yugoslavia was a more elusive and highly debated one. There was no authorization by the UNSC for such actions, which became the strongest basis of legal arguments against it. ${ }^{80}$ However, there may be a few things where one may (elusively) imply its legality and acceptance. First was an implied authorization' from previous UNSC resolutions which declare the situation in Yugoslavia as a threat to international peace and security and thus would need to

73 Preamble paras 2, 3, 4 of the Rome Statute; See also Preamble para 6 indicating erga omnes (i.e. consequence of jus cogens).

Article 8(2)(a) of the Rome Statute.

Preamble para 1 of the UDHR.

76 Karen Parker and Lyn Beth Neylon, "Jus cogens: Compelling the Law of Human Rights," Hastings International and Comparative Law Review, Vol. 12, 1988, p. 442.

Article 41(1) of the ILC Draft on Responsibility, see also its commentary on point 1-3.

Article 1(1), 2(3), 33(1) of the UN Charter.

79 Sudan Tribune, "AU's Opposition to Military Intervention in Libya Ignored by UNSC", http://www.sudantribune. com/spip.php?article38332, accessed on October 2017; VOA News, "Indonesia Urges Ceasefire in Libya", https://www.voanews.com/a/indonesia-calls-for-immediate-ceasefire-in-libya-118830104/137195.html, accessed on October 2017.

80 Christine Chinkin, "The Legality of NATO's Action in the Former Republic of Yugoslavia (FRY) under International Law", International and Comparative Law Quarterly, Vol. 49, Issue 4, 2000, p. 910, at pp. 911-913. 
halt. ${ }^{81}$ The second would be a draft resolution in the Security Council to condemn the NATO intervention, proposed by Russia, which was rejected by a relatively large margin of 12-3.82 The third would be UNSC Resolution S/RES/1244 in 1999 which mentions nothing about the intervention, and this is can arguably be seen as a form of acquiescence on the part of the UNSC. ${ }^{83}$ The fourth justification, which finds little clear authority in the law but used by pro-intervention states in the UNSC sessions ${ }^{84}$ and NATO members before the ICJ, was the fact that it was necessary to avert humanitarian catastrophe. ${ }^{85}$ Although one must admit that the UNSC examples are not always positive, the times of failure of action on part of the UNSC is usually due to the veto rights of the minority despite the overwhelming demand of action by the vast majority of the world. ${ }^{86}$

One thing that could at least be concluded from the previous precedence is that there is indeed recognition for the need of intervention in case of severe humanitarian catastrophes. Such difference in motive and surrounding circumstance brings a very different attitude to it (there are contentions that states endorsing NATO intervention did so regardless of illegality but political motives because not supporting an end to Yugoslavia's crimes will sound immoral). ${ }^{87}$ The problem is on who may do it, as it seems that the most established rules is to only allow the UNSC to either conduct or authorize such intervention.

\section{Humanitarian Intervention: Breach of Jus cogens?}

There are many ways to describe what 'humanitarian intervention' means and differences of opinion in some of those descriptions. However, as explained by Arnold Kanter (referred to as 'armed humanitarian intervention'), there seems no difference in at least the following cumulative characteristics: 88

a. It involves the threat or use of military force,

b. It is an intervention, meaning that it transgresses the sovereignty of another state. Military actions which carried out towards a state with the request or consent of that state would not fall into this category, and

c. It is for humanitarian purposes, meaning that the military force (or otherwise) is used to stop massive inhumane acts occurring in that other state.

\footnotetext{
Although this particular argument is admittedly a very dubious one. See: Christine Gray, Op.cit., pp. 42-43.

82 Ian Williams, "The UN's Surprising Support", https://iwpr.net/global-voices/uns-surprising-support, accessed on October 2017.

33 Christine Gray, Op.cit., p. 43.

84 Ibid., p. 41.

85 Ibid., pp. 44-46.

86 Fajri Matahati Muhammadin, "Can International Law be Enforced Towards its Subjects Within the International Legal Order?", Jurnal Hukum IUS QUIA IUSTUM, Vol. 21, Issue 2, 2014, pp. 175-202, at pp. 181-183.

87 Christine Gray, Loc.cit.

88 Arnold Kanter, "Memorandum to the President", in Alton Frye (ed.), Humanitarian Intervention: Crafting a Workable Doctrine: Three Options Presented as Memoranda to the President, New York: Council on Foreign Relations, 2000, pp. 3-4.
} 
There is no doubt that humanitarian intervention is a use of force. ${ }^{89}$ The question is whether or not humanitarian intervention is the type of use of force that is against the Jus cogens. If one submits to the aforementioned James Green's (extreme) position that The Prohibition is not a rule of Jus cogens, then the conclusion is simple. If the protection of human rights is Jus cogens, while The Prohibition is not, then certainly humanitarian intervention is not a breach of Jus cogens. However, as mentioned earlier, this paper does not submit to that opinion. As this paper contends, it is only when a use of force classified as aggression becomes a breach of Jus cogens. The accepted general definition of aggression is:

"Aggression is the use of armed force by a State against the sovereignty, territorial integrity or political independence of another State, or in any other manner inconsistent with the Charter of the United Nations, as set out in this Definition." 90

The UNGA Resolution actually goes deeper and detailed but it is easy to conclude that prima facie humanitarian intervention is an act of aggression unless the UNSC, in conformity with the UN Charter, determines otherwise "...in the light of other relevant circumstances, including the fact that the acts concerned or their consequences are not of sufficient gravity." ${ }^{91}$ This gives strength to the argument against NATO invasion to Yugoslavia, as, despite the 'alleged acquiescence', the UNSC did not really determine anything, thus one may resort to the prima facie conclusion.

Further, the Resolution decrees "No consideration of whatever nature, whether political, economic, military or otherwise, may serve as a justification for aggression". ${ }^{92}$ Self-defense is generally not included, since, in classic terms, it should not involve invading the territorial integrity or sovereignty of other states (being the one who is invaded). Anticipatory self-defense, though, is problematic as justifies doing the attack to enemy territory first and does lead to extensive debates. ${ }^{93} \mathrm{At}$ this level, consequently, the odds do not seem in the favor towards humanitarian intervention. Conclusions can be more intriguing, though, if one examines from a Jus cogens perspective.

It has been shown that the violations that occur during civil wars indeed come with breaches of Jus cogens. However, humanitarian intervention does

89 Some scholars insist that the humanitarian intervention should include non-military and non-forcible acts also. See: David .J. Scheffer, "Toward a Modern Doctrine of Humanitarian Intervention", University of Toledo Law Review, Vol. 23, 1991, p. 253, at p. 266. However, this proposition will not be used. Not only that this is not part of the scholarly consensus, but since this paper discusses the Prohibition it would be irrelevant to discuss concepts not involving the use of force.

90 Article 1 of the Annex, UNGA Resolution A/RES/3314. This definition was agreed and later reaffirmed in the Rome Statute amendment on the Crime of Aggression.

91 lbid., Article 2 of the Annex.

92 Ibid., Article 5(1) of the Annex.

93 Some of these discourses are legal-theoretical, others discuss on the practicalities on the boundaries where there is too much risk of multi-interpretation which would endanger world peace. See: James Mulcahy and Charles O. Mahony, "Anticipatory Self-Defence: A Discussion of the International Law", Hanse Law Review, Vol. 2, No. 2, 2006, pp. 231-248. 
seem to indeed fall within the category of breach of Jus cogens as well. It is hard to positively prove that humanitarian intervention has universally been accepted to be an exception to The Prohibition, while it has been established before how important recognition is towards identifying a rule of Jus cogens. While the practice itself remains controversial (with all the pros and cons to it), ${ }^{94}$ a recognition of a Jus cogens status is unthinkable.

However, on the other hand, there is no sufficient recognition that humanitarian intervention is a breach of Jus cogens either. As mentioned before, a draft resolution to condemn the NATO failed by a large margin of 12-3 votes and no other massive oppositions other than Russia and China. The previously mentioned elusive acquiescence also indicates unclarity on the matter.

Compare to other cases. With regards to matters already established as Jus cogens (e.g. war crimes, crimes against humanity, genocide, and aggression), international response and recognition has always been consistent, mostly quoting UNGA Resolutions to indicate more representative global support:

a. The Iraq invasion of Kuwait in 1990, on the invasion and war crimes, the UNGA voted almost unanimously (only 1 voted against and no abstentions) ${ }^{95}$ through UNGA Resolution A/RES/45/170.

b. The Rwanda genocide, the UNGA adopted Resolution Number A/RES/49/206 without vote 96

c. The Yugoslavia situation on genocide, war crimes, and crimes against humanity, the UNGA adopted Resolution Number A/RES/47/147 without vote. ${ }^{97}$

d. The ongoing Syria civil war, on the war crimes and crimes against humanity (133 for members for, 12 against, and 31 abstained) ${ }^{98}$ through UNGA Resolution A/ RES/66/253 B. This resolution also condemns the UNSC for failing to act. ${ }^{99}$

Having all that said, the Jus cogens debate reaches an awkward conclusion. One cannot conclude that humanitarian intervention has been recognized that far as to derogate from a Jus cogens norm. However, one cannot conclude either that humanitarian intervention is a part of The Prohibition that has achieved Jus cogens status.

\section{E. Conclusion}

This paper is begun by explaining the nature of Jus cogens norms and how it is determined. Jus cogens are the highest norms in international law which in substance

94 See generally: Ryan Goodman, Op.cit.; Christie Chinkin, Op.cit.; Christine Gray, Op.cit., pp. 33-51.

95 United Nations, "Resolutions adopted by the General Assembly at its 45th session", http://research.un.org/en/ docs/ga/quick/regular/45, accessed on October 2017.

96 United Nations, "Resolutions adopted by the General Assembly at its 49th session", http://research.un.org/en/ docs/ga/quick/regular/49, accessed on October 2017.

97 United Nations, "Resolutions adopted by the General Assembly at its 47th session", http://research.un.org/en/ docs/ga/quick/regular/47, accessed on October 2017.

98 United Nations, "Resolutions adopted by the General Assembly at its 66th session", http://research.un.org/en/ docs/ga/quick/regular/66, accessed on October 2017.

99 The Preambulatory Clause of United Nations General Assembly Resolution A/RES/66/253 B, para. 16. 
represents what is considered most important, so that it is so evil and unacceptable to derogate from them. However, to determine this, one would require some universal recognition as such and this is where the stage of the debate is set.

The paper then continued to explore the nature of The Prohibition and the extent of its' Jus cogens status. It is reaffirmed that it is true that The Prohibition is indeed a Jus cogens norm. However, there seems to be a limit to what extent is the use of force a Jus cogens. It is found that not all uses of force are parts of the Jus cogens, as there are exceptions.

It is found that there are two angles from which to reach the conclusion of this paper. The first is that humanitarian intervention simply does not satisfy the definition of what kind of use of force that is recognized as a violation of Jus cogens, as it might not establish the 'contrary to the UN Charter' element. The second, more importantly, the act of humanitarian intervention has not been met with a widespread categorical rejection from the international community. Rather, there are many supports on many occasions, while Jus cogens requires recognition for it to become a Jus cogens in the first place. All of these leads to the inevitable conclusion: humanitarian intervention is a use of force which does not breach Jus cogens.

The controversy of humanitarian intervention may very well persist. Scholars will forever argue to what extent humanitarian intervention can be justified and what are the criteria. Whether a particular situation would require humanitarian intervention, and what kind of humanitarian intervention would truly benefit the situation, all would be part of the discourse. However, at least for this paper, the issue of Jus cogens is resolved.

\section{References \\ Books}

Abdul Ghofur Anshori, Filsafat Hukum: Sejarah, Aliran, Dan Perkembangannya, Gadjah Mada Press, Yogyakarta, 2006.

Bassiouni, M Cherif, "International Crimes: Jus cogens and Obligatio Erga Omnes", Law \& Contemporary Problems, Volume 59, Issue 4, 1996.

Borain, Alex, "Truth and Reconciliation in South Africa: The Third Way", in R.I. Rotberg and D. Thompson (eds.), Truth v. Justice: The Morality of Truth Commission, Princeton University Press, Princeton, 2000.

Czapliński, Władysław, "Jus cogens and the Law of Treaties", in Christian Tomuschat and Jean-Marc Thouvenin (eds.), The Fundamental Rules of the International Legal Order: Jus cogens and Erga Omnes, Martinus Nijhoff Publishers, LeidenBoston, 2006.

Gardner, Bryan A. (ed.), Blacks Law Dictionary, $9^{\text {th }}$ edition, Thomson West, Minnesota, 2009.

Gray, Christine, International Law and the Use of Force, $3^{\text {rd }}$ edition, Oxford University Press, New York, 2008. 
Kadelbach, Stefan, "Jus cogens, Obligations Erga Omnes, and Other Rules - The Identification of Fundamental Norms", in Christian Tomuschat and Jean-Marc Thouvenin (eds.), The Fundamental Rules of the International Legal Order: Jus cogens and Erga Omnes, Martinus Nijhoff Publishers, Leiden-Boston, 2006.

Kanter, Arnold. "Memorandum to the President", in Alton Frye, Humanitarian Intervention: Crafting a Workable Doctrine: Three Options Presented as Memoranda to the President, Council on Foreign Relations, New York, 2000.

Murphy, Mark C., "Natural Law Theory", in M.P. Golding and W.A. Edmundson (eds.), The Blackwell Guide to the Philosophy of Law and Legal Theory, Blackwell Publishing, Oxford, 2005.

Shaw, Malcolm N., International Law, $6^{\text {th }}$ edition, Cambridge University Press, New York, 2008.

Sudikno Mertokusumo, Mengenal Hukum: Suatu Pengantar, Liberty Press, Yogyakarta, 2006.

\section{Other Documents}

BBC News, "Darfur Death Toll Rises to Two-Year High in Sudan", http://www.bbc. co.uk/news/10259604, accessed on October 2017.

Bethlehem, Daniel, "Self-Defense against an Imminent or Actual Armed Attack by Nonstate Actors", American Journal of International Law, Vol. 106, Issue 4, 2012.

Chinkin, Christine, "The Legality of NATO's Action in the Former Republic of Yugoslavia (FRY) under International Law", International and Comparative Law Quarterly, Vol. 49, Issue 4, 2000.

CNN, "Syrian Civil War Fast Facts", https://edition.cnn.com/2013/08/27/world/ meast/syria-civil-war-fast-facts/index.html, accessed on October 2017.

Fajri Matahati Muhammadin, "Can International Law be Enforced Towards its Subjects Within the International Legal Order?", in Jurnal Hukum IUS QUIA IUSTUM, Vol. 21, Issue 2, 2014.

Goodman, Ryan, "Humanitarian Intervention and Pretexts for War", American Journal of International Law, Vol. 100, Issue 1, 2006.

Green, James A., "Questioning the Peremptory Status of the Prohibition of the Use of Force", Michigan Journal of International Law, Vol. 32, 2010.

Huffington Post, "Iraq Death Toll Reaches 500,000 Since Start Of U.S.-Led Invasion, New Study Says", http://www.huffingtonpost.com/2013/10/15/iraq-deathtoll n 4102855.html, accessed on October 2017.

Human Rights Watch, "Indonesia: The Violence in Central Kalimantan (Borneo)" http://www.hrw.org/legacy/backgrounder/asia/borneo0228.htm, accessed on October 2017.

International Center for Transitional Justice, "Transitional Justice in the Former Yugoslavia", 2009, http://ictj.org/sites/default/files/ICTJ-FormerYugoslaviaJustice-Facts-2009-English.pdf, accessed on October 2017. 
International Criminal Tribunal for the Former Yugoslavia, "About the ICTY", http:// www.icty.org/en/about, accessed on October 2017.

Linderfalk, Ulf, "Normative Conflict and the Fuzziness of the International lus Cogens Regime", Zeitschrift Für Ausländisches Öffentliches Recht Und Völkerrecht, Vol. 69, 2009.

, "The Effect of Jus cogens Norms: Whoever Opened Pandora's Box, Did You Ever Think about the Consequences?" in European Journal of International Law, Vol. 18, Issue 5, 2007.

Mulcahy, James and Charles O. Mahony, "Anticipatory Self-Defence: A Discussion of the International Law", Hanse Law Review, Vol. 2, No. 2, 2006.

Naqvi, Yasmin, "Amnesty for War Crimes: Defining the Limits of International Recognition", International Review of the Red Cross, Vol. 85, Issue 851, 2003.

Parker, Karen, and Lyn Beth Neylon, "Jus cogens: Compelling the Law of Human Rights", Hastings International and Comparative Law Review, Vol. 12, 1988.

Scharf, Michael P., "The Amnesty Exception to the Jurisdiction of the International Criminal Court", Cornell International Law Journal, Vol. 32, 1999.

Scheffer, David J., "Toward a Modern Doctrine of Humanitarian Intervention", University of Toledo Law Review, Vol. 23, 1991.

Sudan Tribune, "AU's Opposition to Military Intervention in Libya Ignored by UNSC", http://www.sudantribune.com/spip.php?article38332, accessed on October 2017.

Telegraph UK, "Everyone in Syria Is Bad Now', Says UN War Crimes Prosecutor as She Quits Post", http://www.telegraph.co.uk/news/2017/08/07/everyone-syriabad-now-says-un-war-crimes-prosecutor-quits-post/, accessed on October 2017.

United Nations Treaty Collection, "Charter of the United Nations and Statute of the International Court of Justice", http://treaties.un.org/Pages/ViewDetails. aspx?src=TREATY\&mtdsg no=l-1\&chapter=1\&lang=en, accessed on October 2017.

United Nations, "Resolutions Adopted by the General Assembly at its 45th Session", http://research.un.org/en/docs/ga/quick/regular/45, accessed on October 2017.

, "Resolutions Adopted by the General Assembly at its 66th Session", http://research.un.org/en/docs/ga/quick/regular/66, accessed on October 2017.

, "Resolutions Adopted by the General Assembly at its 47th Session", http://research.un.org/en/docs/ga/quick/regular/47, accessed on October 2017.

, "Resolutions Adopted by the General Assembly at its 49th Session", http://research.un.org/en/docs/ga/quick/regular/49, accessed on October 2017. 
Williams, Ian, "The UN's Surprising Support", https://iwpr.net/global-voices/unssurprising-support, accessed on October 2017.

Wortel, Eva, "Humanitarians and Their Moral Stance in War: The Underlying Values", International Review of the Red Cross, Vol. 91, Issue 876, 2009.

\section{Legal Documents}

Charter of the United Nations 1945.

Universal Declaration of Human Rights 1948.

First Geneva Convention for the Amelioration of the Condition of the Wounded and Sick in Armed Forces in the Field 1949.

Second Geneva Convention for the Amelioration of the Condition of Wounded, Sick and Shipwrecked Members of Armed Forces at Sea 1949.

Third Geneva Convention relative to the Protection of Civilian Persons in Time of War 1949.

Fourth Geneva Convention relative to the Treatment of Prisoners of War 1949.

International Covenant on Civil and Political Rights 1966.

Vienna Convention on the Law of Treaties between States 1969.

Convention on the Elimination of All Forms of Discrimination Against Women 1979. Convention on the Rights of the Child 1989.

Rome Statute of the International Criminal Court 1998.

Draft Articles on Responsibility of States for Internationally Wrongful Acts 2001.

Rome Conference Resolution No. RC/Res.6.

United Nations General Assembly Resolution A/RES/45/170.

United Nations General Assembly Resolution A/RES/3314.

United Nations General Assembly Resolution A/RES/49/206.

United Nations General Assembly Resolution A/RES/47/147.

United Nations General Assembly Resolution A/RES/66/253 B.

United Nations Security Council Resolution S/RES/1244.

United Nations Security Council Resolution S/RES/1973.

International Court of Justice, Military and Paramilitary Activities in and against

Nicaragua (Nicaragua v. United States of America), Judgment, I.C.J. Reports, 1986.

Advisory Opinion, I.C.J. Reports, 1996.

International Criminal Tribunal for the former Yugoslavia, Prosecutor vs Furundzija, Trials Chamber Judgment, IT-95-17/1-T, 1998.

Judge Mahomed's Dissenting Opinion in Constitutional Court of South Africa, Azanian Peoples Organization (AZAPO) and Others v President of the Republic of South Africa and Others, CCT17/96, ZACC 16, 1996. 
House of Lords, R. v Bow Street Stipendiary Magistrate Ex. P. Pinochet Ugarte, No.

3, 1 A.C., 2000.

Reports of the International Law Commission to the General Assembly, U.N. Doc.

A/6309/Rev.1, 1966 in Year Book of the International Law Commission Vol. II, U.N. Doc. A/CN.4/SER.A/1966/Add.1. 